\title{
Design flow duration curves for environmental flows estimation in Damodar River Basin, India
}

\author{
Ravindra Kumar Verma ${ }^{1} \cdot$ Shankar Murthy $^{1} \cdot$ Sangeeta Verma $^{1}$. \\ Surendra Kumar Mishra ${ }^{2}$
}

Received: 5 August 2014/ Accepted: 7 October 2016/Published online: 1 November 2016

(c) The Author(s) 2016. This article is published with open access at Springerlink.com

\begin{abstract}
In this study, environmental flows (EFs) are estimated for six watersheds of Damodar River Basin (DRB) using flow duration curve (FDC) derived using two approaches: (a) period of record and (b) stochastic approaches for daily, 7-, 30-, 60-day moving averages, and 7-daily mean annual flows observed at Tenughat dam, Konar dam, Maithon dam, Panchet dam, Damodar bridge, Burnpur during 1981-2010 and at Phusro during 1988-2010. For stochastic FDCs, 7-day FDCs for 10, 20-, 50 - and 100-year return periods were derived for extraction of discharge values at every $5 \%$ probability of exceedance. FDCs derived using the first approach show high probability of exceedance $(5-75 \%)$ for the same discharge values. Furthermore, discharge values of 60-day mean are higher than those derived using daily, 7-, and 30-day mean values. The discharge values of $95 \%$ probability of exceedance (Q95) derived from 7Q10 (ranges from 2.04 to 5.56 cumec) and 7Q100 (ranges from 3.4 to 31.48 cumec) FDCs using the second approach are found more appropriate as EFs during drought/low flow and normal precipitation years.
\end{abstract}

Keywords Flow duration curve · Environmental flows · Damodar river basin

Ravindra Kumar Verma

ravindraverma.nitie@gmail.com

1 Environmental Engineering and Management Group, National Institute of Industrial Engineering (NITIE), Vihar Lake, Mumbai 400087, Maharashtra, India

2 Department of Water Resource Development and Management, Indian Institute of Technology-Roorkee, Roorkee, 247667 Uttarakhand, India

\section{Introduction}

The flow duration curve (FDC) is a graphical representation of the observed historical variation of stream flows with different time resolutions such as daily (1-day), weekly (7-day) monthly (30-day), and seasonal at the sampling site that show the percent of time specified discharges will be equaled or exceeded over different time scales of interest (Vogal and Fennessey 1994; Smakhtin 2001). Therefore, it is an informative method that represents the flow regime's properties for a river basin. Typically, low flows during prolonged dry spells are exceeded majority of the time while high flows are exceeded infrequently. In addition, its entire section of FDC is interpreted as an index of ground water/and or subsurface flow contribution to stream flow, subsurface catchment storage for a particular river basin (Vogal and Fennessey 1994). The curve can also be drawn for arbitrary return period at suitable scales for stochastically evaluating the fluctuation of stream flow (Sugiyama et al. 2003).

In hydrology, FDC has credibility and acceptance among many researchers and practitioners in hydrological studies, river ecology, and various water resources problems. It has a long application history in the field of irrigation, water supply, hydro-electric power planning (Vogal and Fennessey 1994), selection of waste water treatment plant capacity (Male and Ogawa 1984), river/reservoir/lake sedimentation studies, wetland inundation mapping, instream flow assessments (Reiser et al. 1989; Tharme 2003), waste load allocation (Searcy 1959; Chen and Ma 2007), water resources allocation, reservoir management (Alaouze 1989), low/flood frequency analysis (Smakhtin 2001), flood damage assessment, selection of an optimal water resources project, water-use engineering, ecological reserve (Hughes and Hannart 2003), aquatic biodiversity

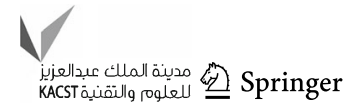


(Poff et al. 1997; Brown and Ford 2002), stochastic evaluation of low flows (Sugiyama et al. 2003), channel design including the evaluation of sediment transport capacity, and habitat condition.

Although, the recent years have seen the increased interest to FDC in environmental applications including stream channel realignment or reconstruction to maintain riverian functions like healthy aquatic ecosystem, water quality and quantity, encourage breeding of species of fish. For this, specific flows or suitable design flows must be selected. There is no globally accepted guideline available for design low flows for particular purposes. A general consensus for estimating design low flows is to use recession part (70-99\%) of the FDC of available period of record (POR) and/or Annual FDC (AFDC) of daily discharge data to protect water environment with a marginal safety (Smakhtin 2001). For example, Q95 is often used for determining EFs in downstream reaches of impoundment in a river system for maintaining riverian ecosystem in the state of good health (Jha et al. 2008). The livelihood associated with Q95 quartile can be described by return period of specific year. It is widely used in the analysis of the risk of extreme low flow period. In addition, 7-day 10 years (7Q10) low flow threshold has typically been recognized as design flow during low flow condition, a need to maintain aquatic life protection.

Thus, it is in order to explain the application of FDC to design EFs for riverian functions. The objectives of the present study are to: (i) extend FDC application to extreme low flows determination, and (ii) assess EFs in six different watersheds in DRB.

\section{Historical background}

FDCs have long history in hydrological applications as they are easy to use, explain, and understand as graphical display. The first earliest use is attributed to Clemens Herschel in 1880, but have been in general use since about 1915 (Foster 1934). However, their use is often criticized several times due to traditional long term POR and on-site daily runoff measurements (Vogal and Fennessey 1994; Castellarin et al. 2004). Another drawback is that it is not suitable for extracting stochastic hydrological information, i.e., low/drought flow situation for water resource management and planning (Sugiyama et al. 2003) and, also no procedures for computing theoretically confidence intervals (CIs) are available.

Despite the limitations of PORFDC, annual, water year or calendar year FDC has the potential to circumvent the limitations (Vogal and Fennessey (1994). The AFDC represents a typical year wherein the interpretation is not affected by abnormal observations during the PORs. It also allows derivation of design FDC of various return periods in a non-parametric framework, useful in hydrologic planning and design for special cases, i.e., annual minimum low flows (Vogal and Fennessey 1994). The AFDC approach is also capable of obtaining the uncertainty level of the design flow by generating the CI rather than a fixed value. This will helpful to take optimistic decision for long term plan. Other probabilistic and parametric representations of FDC have been suggested by Quimpo et al. (1983), Mimikou and Kaemaki (1985), Fennessey and Vogel (1990), and LeBoutillier and Waylen (1993).

Many hydrologists and/or engineers have been interested in the construction of the FDC at ungauged site using different techniques such as regionalization, non-linear spatial interpolation, synthetic flow time series simulation method (low flows map grid profiles) (Smakhtin 2001). Searcy (1959) provided a comparison of the daily, monthly and annual FDCs for a river basin. He suggested interpretation of AFDCs for examining the year-to-year variations in stream flow. Further, he also suggested using climatic years beginning on April 1 when constructing AFDCs to avoid the arbitrary division of low flow periods. Castellarin et al. (2004) introduced an approach similar to discharge index to model relationships between FDC and AFDCs of daily discharges. This method can reproduce FDC, and also mean, median, and variance of AFDCs without using assumptions to seasonal and persistence structure of daily discharges.

Male and Ogawa (1982) suggested the use of composite diagrams, in which tradeoff between plant efficiency, exceedance probability of not violating water quality standard and project cost is examined. Using FDC based on different stream flow duration allows one to further evaluate the consequences of changes in the definition of the design stream flow event in terms of the water quality standard, and treatment plant efficiency.

Alaouze $(1989,1991)$ developed the procedures based on FDC, for estimation of optimal release schedule from reservoirs, where each release has a unique reliability. Vogal and Fennessey (1994) describe how to associate CIs, average return periods, and annual reliabilities with an annual-based FDC.

Pitman (1993) and Mallory and McKenzie (1993) illustrated the use of FDCs in design of flow diversions. Gustard and Wesselink (1993), Lanen et al. (1997), and Smakhtin et al. (1998) used an FDC as a tool for rainfallrunoff model calibration and/or for the comparison of flow time series simulated for different scenarios of development. LeBoutillier and Waylen (1993) introduced an annual interpretation of FDCs for the purpose of selecting a suitable probability density function for daily stream flow.

Wilby et al. (1994) used FDC to assess the effects of different climate scenarios on stream flow with particular 
reference to low flows. Further, Vogal and Fennessey (1994) suggested that using the median of the AFDC represents the frequency and magnitude of streamflow in a typical (but hypothetical) year. The median AFDC is computed as the median value of stream flow (across the $n$ years of stream flow) for each exceedance probability $p$ (there are 365 exceedance probabilities associated with the 365 days in each year), and it represents the distribution of daily stream flow in a typical or median hypothetical year. Un1ike the traditional PORFDC, the interpretation of the median AFDC is minimally affected by the observation of abnormally wet or dry periods during the POR.

Hughes and Smakhtin (1996a, b) suggested a nonlinear spatial interpolation approach (based on FDCs) for patching and extension of observed daily flow time series, which has latter been extended to generation of flow time series at the ungauged sites (Smakhtin et al. 1997) and to the restoration of natural stream flow sequences in regulated rivers (Smakhtin et al. 1998). Hughes et al. (1997) developed an operating rule model which is based on FDCs, which is designed to convert the original tabulated values of estimated ecological instream flow requirements for each calendar month into a time series of daily reservoir releases.

Smakhtin (2001) presented a comprehensive review of low flow hydrology covering such as issues as generating mechanisms, estimation methods and applications. He indicated that the range 70-99\% (Q70 to Q99) of a FDC can be used as design low flow event. He also suggested that a 7-day period which eliminates day-to-day variations of river flow is less sensitive to measurement errors. Practically, a 7-day low flow better represents the drought conditions of concern and can be used more effectively in EFs assessment for water resource management (Jha et al. 2008).

\section{Materials and methodology}

\section{Study area}

The present study was carried out in six different watersheds of the highly regulated Damodar River Basin (DRB), India. The basin is mainly drained by rivers Damodar and Barakar into the states of Jharkhand and West Bengal. Its geographical boundary lies between $22^{\circ} 15^{\prime} \mathrm{N}$ to $24^{\circ} 30^{\prime} \mathrm{N}$ latitude and $84^{\circ} 45^{\prime} \mathrm{E}$ to $88^{\circ} 30^{\prime} \mathrm{E}$ longitude (Fig. 1).

The Damodar river is a small rainfed river $(541 \mathrm{~km}$ long), originating from the Khamerpet hill (elevation $1068 \mathrm{~km})$. It is situated between latitudes $23^{\circ} 22^{\prime} \mathrm{N}$ to $24^{\circ} 8^{\prime} \mathrm{N}$ latitude and $84^{\circ} 37^{\prime} \mathrm{E}$ to $86^{\circ} 53^{\prime} \mathrm{E}$ longitude and total geographical area of the basin is $9907.8 \mathrm{sq} . \mathrm{km}$. The river flows through granites and granitic-gneisses of Archeans, sandstones and shales of the Gondwanas and the recent alluvials. Gondwana rocks consisting of sandstones, shales and fire clays with coal seams form the part of the catchments of Tenughat, Panchet, and Durgapur barrage, and cross the cities Ramgarh, Dhanbad, Asansol, Durgapur, Bardwan, and Howrah before ultimately joining the lower Ganga (Hooghly estury) at Shayampur $55 \mathrm{~km}$ downstream of Howrah. It has a number of tributaries and sub-tributaries such as Konar, Garganalla, Jamunia, Khudia, Katri, Nunia and Tamla nalla. It has two dams at Tenughat and Panchet.

The river Barakar is originating from the hills of Hazaribagh and situated between latitudes $32^{\circ} 43^{\prime} \mathrm{N}$ to $24^{\circ} 31^{\prime} \mathrm{N}$ latitude and $85^{\circ} 70^{\prime} \mathrm{E}$ to $86^{\circ} 53^{\prime} \mathrm{E}$ longitude and total geographical area of the catchment is $7026 \mathrm{sq}$. km. It runs almost parallel to river Damodar in about $225 \mathrm{~km}$ length in eastern direction and joins Damodar close to Disergarh in West Bengal. The important tributaries of the river are Saghar, Barsati, Bakra, Igra, Usri, Chikri, Khudia, Beri, and Rajoya. It also has two dams at Tilaya and Maithon.

The whole river basin experiences tropical climate; winters are cold, summers are hot and the temperature difference between the two seasons is significant. Mean annual precipitation over the whole basin varies from 765 to $1850 \mathrm{~mm}$ (Avg. $1300 \mathrm{~mm}$ ), which is distributed unevenly in space and time. Usually, rainfall occurs during monsoon season from May to August month.

\section{Data collection and estimation sites}

Daily mean discharge data for 9 gauged sites were collected from the Maithon Reservoir Office (MRO) of Damodar Valley Corporation (DVC), Jharkhand. Then, preliminary scrutiny of the data was carried out according to length of time-series, and locating the gaps, it was found that of only 6 sites could be used in the study. The locations and characteristics of these selected sites are summarized in Table 1 and shown in Fig. 1.

The hydrological analysis was carried out using these datasets. Calculated mean monthly provides information about flow variability in each watershed. Figure 2 shows that discharge from the Panchet site is more as compared to the other sites of DRB. However, the peak discharge is only at Maithon site, which may be due to comparatively heavy rainfall. These flow aspects indicate that rainfall and runoff discharge is valuable for water resource.

\section{Flow duration curve}

In this study, two approaches were applied to develop FDCs: 1. POR FDC and 2. Stochastic FDC as suggested by Sugiyama et al. (2003) and Jha et al. (2008). 


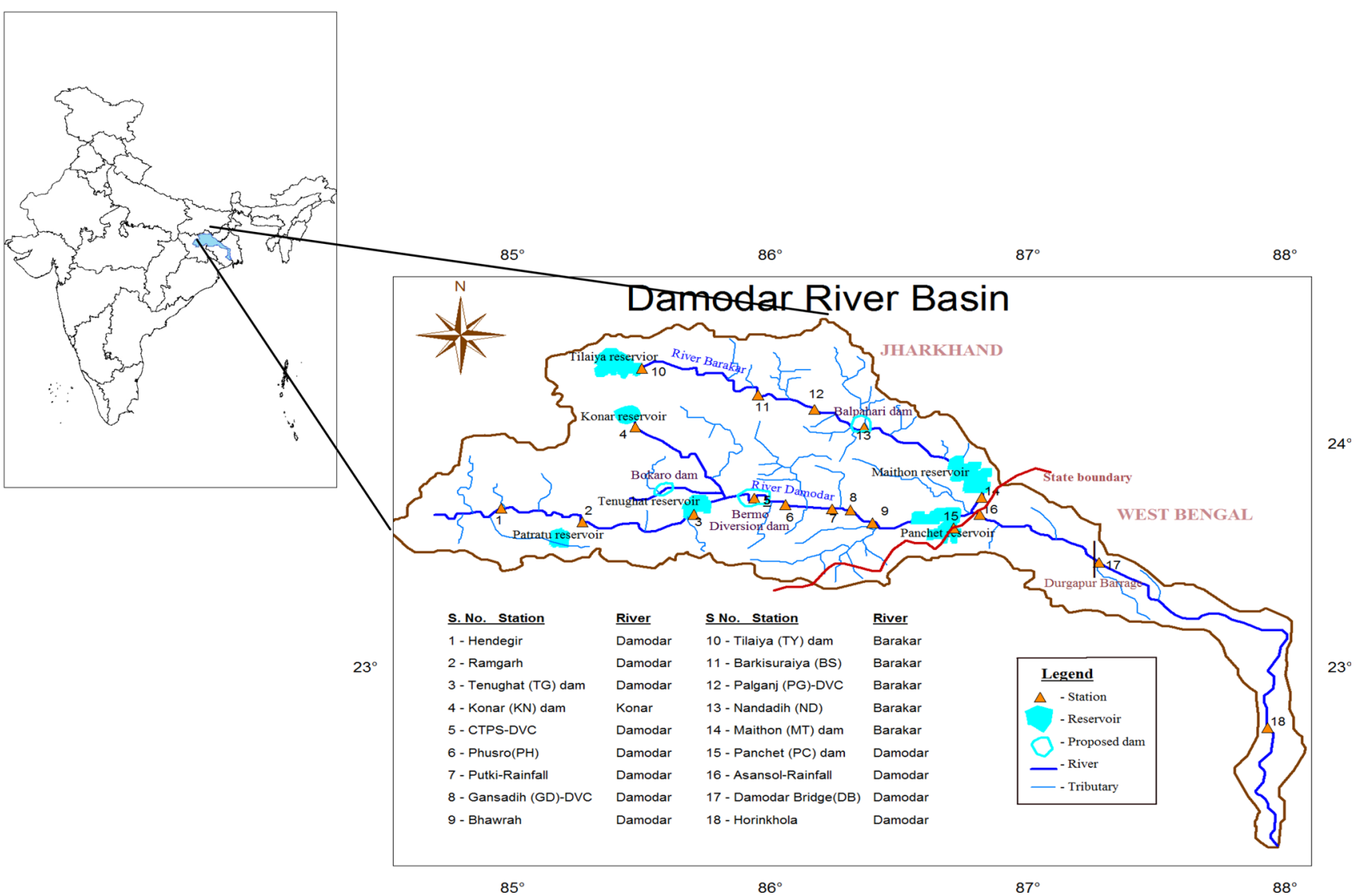

Fig. 1 Location of gauging sites in DRB

Table 1 Description of selected gauging sites in DRB

\begin{tabular}{|c|c|c|c|c|c|c|c|}
\hline S. no. & Site (number) & River & $\begin{array}{l}\text { Length of } \\
\text { record }\end{array}$ & Location & $\begin{array}{l}\text { Drainage area } \\
\left(\mathrm{km}^{2}\right)\end{array}$ & $\begin{array}{l}\text { Average annual } \\
\text { precipitation }(\mathrm{cm})\end{array}$ & $\begin{array}{l}\text { Annual runoff } \\
(\text { Ha-m) }\end{array}$ \\
\hline 1. & TG dam (3) & Damodar & 1981-2010 & $23^{\circ} 44^{\prime} \mathrm{N} 85^{\circ} 55^{\prime} \mathrm{E}$ & 3393 & 132.08 & 245,500 \\
\hline 2. & $\mathrm{KN}$ dam (4) & Konar & 1981-2010 & $23^{\circ} 43^{\prime} \mathrm{N} 85^{\circ} 30^{\prime} \mathrm{E}$ & 997.1 & 132.08 & 55,507 \\
\hline 3. & Phusro (6) & Damodar & 1988-2010 & $23^{\circ} 45^{\prime} \mathrm{N} 86^{\circ} 00^{\prime} \mathrm{E}$ & 5352 & - & - \\
\hline 4. & MN dam (14) & Barakar & 1981-2010 & $23^{\circ} 78^{\prime} \mathrm{N} 86^{\circ} 81^{\prime} \mathrm{E}$ & 6294 & 114.17 & 261,499 \\
\hline 5. & PN dam (15) & Damodar & 1981-2010 & $23^{\circ} 40^{\prime} \mathrm{N} 86^{\circ} 44^{\prime} \mathrm{E}$ & 10,966 & 114.17 & 453,923 \\
\hline 6. & DB, Burnpur (17) & Damodar & 1981-2010 & $24^{\circ} 06^{\prime} \mathrm{N} 86^{\circ} 13^{\prime} \mathrm{E}$ & 19,555 & 132.08 & - \\
\hline
\end{tabular}

\section{Approach 1: period-of-record flow duration curve}

The period-of-record FDC is computed by inserting the cumulative density function (CDF) of different 1-, 7-, 30-, 60 -day times series data. The curve is generally constructed using frequency analysis of recorded discharge data without providing information regarding the inter-annual variability of flows and steps are as follows:

(a) Calculate daily or $n$-day (i.e., 7, 30, 60) moving average from time series data.

(b) Sort the flow data in order of decreasing flow. (c) Assign a unique ranking number $m$ to each flow, starting with 1 for the maximum flow to $n$ for the minimum flow $q_{i}(i=1,2,3,4, \ldots n)$, where $n$ is the number of flow measurements.

(d) Find the corresponding probability $P$ of exceeding individual flow i. $P_{i}$ as Eq. (1):

$P_{i}=P\left(Q>q_{i}\right)=1-P\left(Q \leq q_{i}\right)$

(In the present study, Weibull method $\left(P=\frac{m}{n+1} \times 100\right)$ was used), and

(e) The flow-probability relationship is typically presented as a log normal plot. 
Fig. 2 Variation of mean monthly discharge at a Tenughat dam; b Konar dam; c Phusro; d Maithon dam; e Panchet dam; f Damodar bridge, Burnpur site
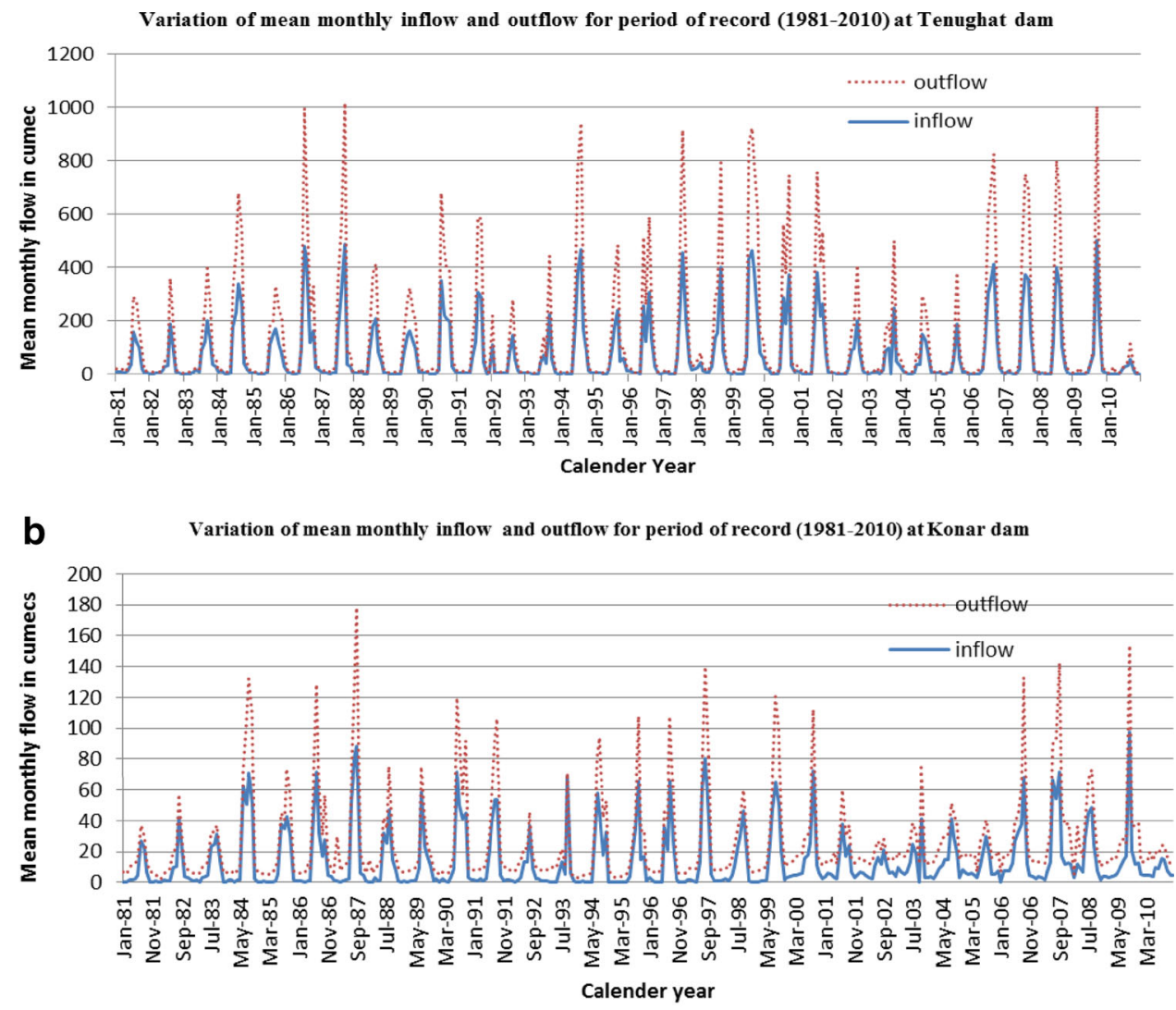

C Variation of mean monthly flow for period record (1988-2010) at Phusro

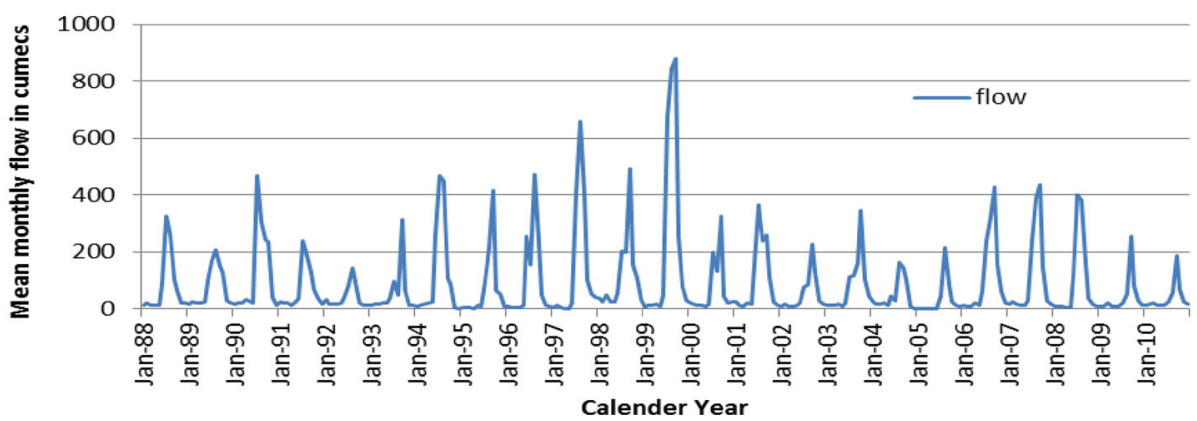

Approach 2: stochastic flow duration curve

To overcome difficulties of PORFDC, stochastic FDC was used based on the principle of order statistics. In this approach, recorded flow data of $n$ years were decomposed into individual years and generated FDC for individual years using 7-day moving mean and plotting as previously discussed in steps a to e. The 7-day moving average eliminates day-to-day variation or smoothening out the high frequency fluctuations of time series data. The FDCs for various return periods were also developed using the distribution characteristics of a set of probability plots of stream, calculated by Weibull plotting formula, at suitable time intervals from 0 to $100 \%$ on the time axis. These curves were used to evaluate the severity of low flow regimes in six different watersheds of DRB. The steps followed to obtain the FDCs of various return periods are given below:

(a) After construction of AFDC, read values of daily discharge at every $5 \%$ probability of exceedance.

(b) Make separate table for each year discharge vs probability of exceedance.

(c) Rank in ascending order of the discharge values read from each AFDCs using Eq. 1 of a given $N$ year period.

(d) Calculate the plotting position by using Weibull plotting formula $\left(P=\frac{m}{n+1} \times 100\right)$, rationally select the type probability paper to be used, and plot the data on the probability paper. 

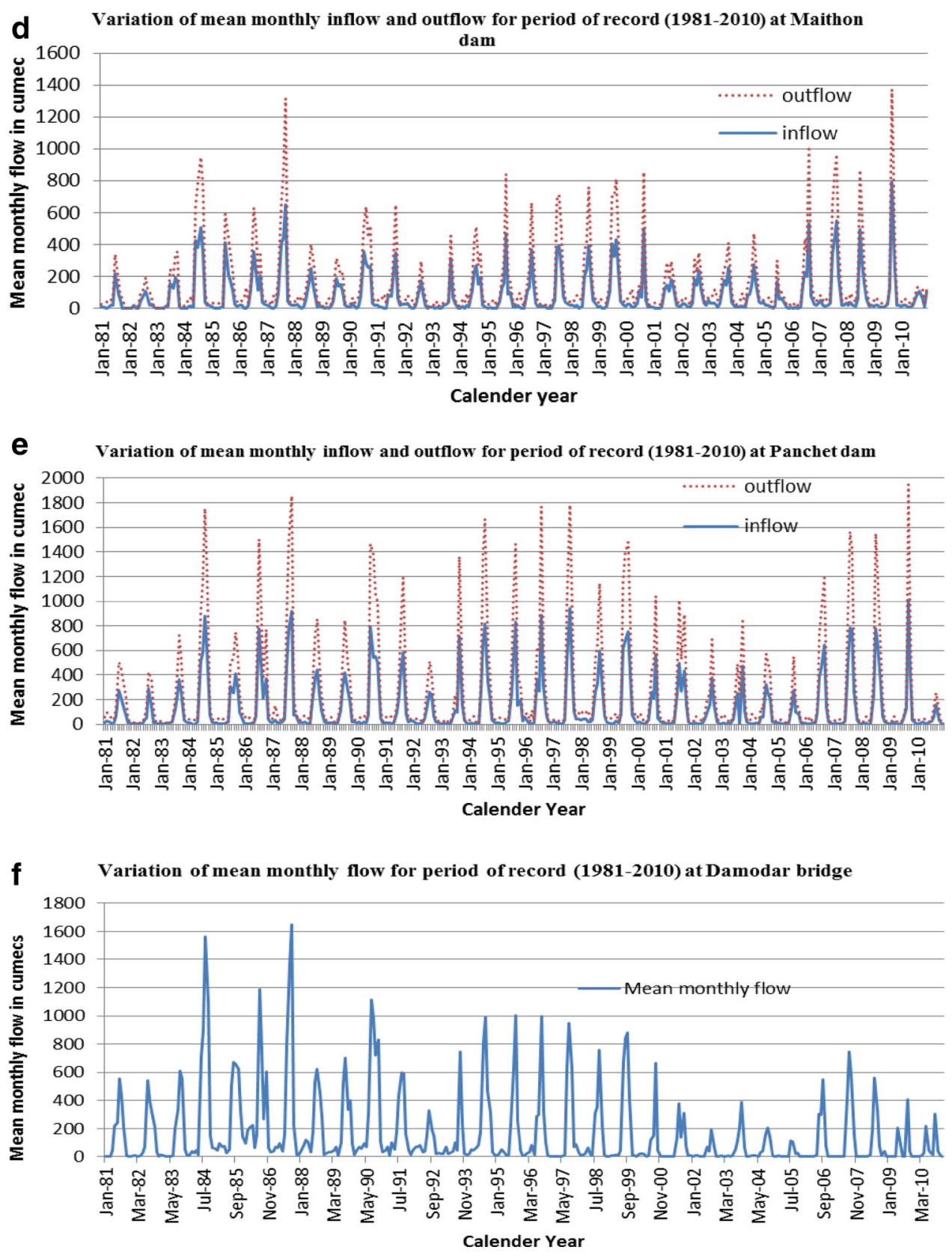

Fig. 2 continued

(e) Visually fit a straight line through the estimated extreme values.

(f) Using straight line equation, get the discharge value down from the best fit line at the chosen probability value for various return periods such as 1-, 2-, 5-, 10-, 20-, 50-, and 100-year.

(g) Tabulate these values and then repeat steps 3-6 at suitable time intervals from 0 to $100 \%$ of the time axis and,

(h) Plot probability daily discharge values read at suitable intervals and draw a smooth FDC of various return periods of 1-, 2-, 5-, 10-, 20-, 50-, and 100-year.
It is to be noted that the above steps a to $h$ were used only for 7-day mean discharge data sets separately to estimate the FDCs of return period of 1-, 2-, 5-, 10-, 20-, 50-, and 100-year. Although it can be used for interest m-day mean discharge, the developed FDC drawn for different return periods was analyzed to estimate the most suitable flow values in view of conserving the ecosystem and protecting available water resources in DRB. In the present study, the value of probability of exceedance equal to $95 \%$ (Q95) was chosen as "design EFs". Because, the basin has extremely low flows during lean period and the ecosystem (flora and fauna) manages with the severity of low flows very well. 
Fig. 3 Comparisons of POR FDCs for daily, -7, -30, and 60-day of selected sites in DRB
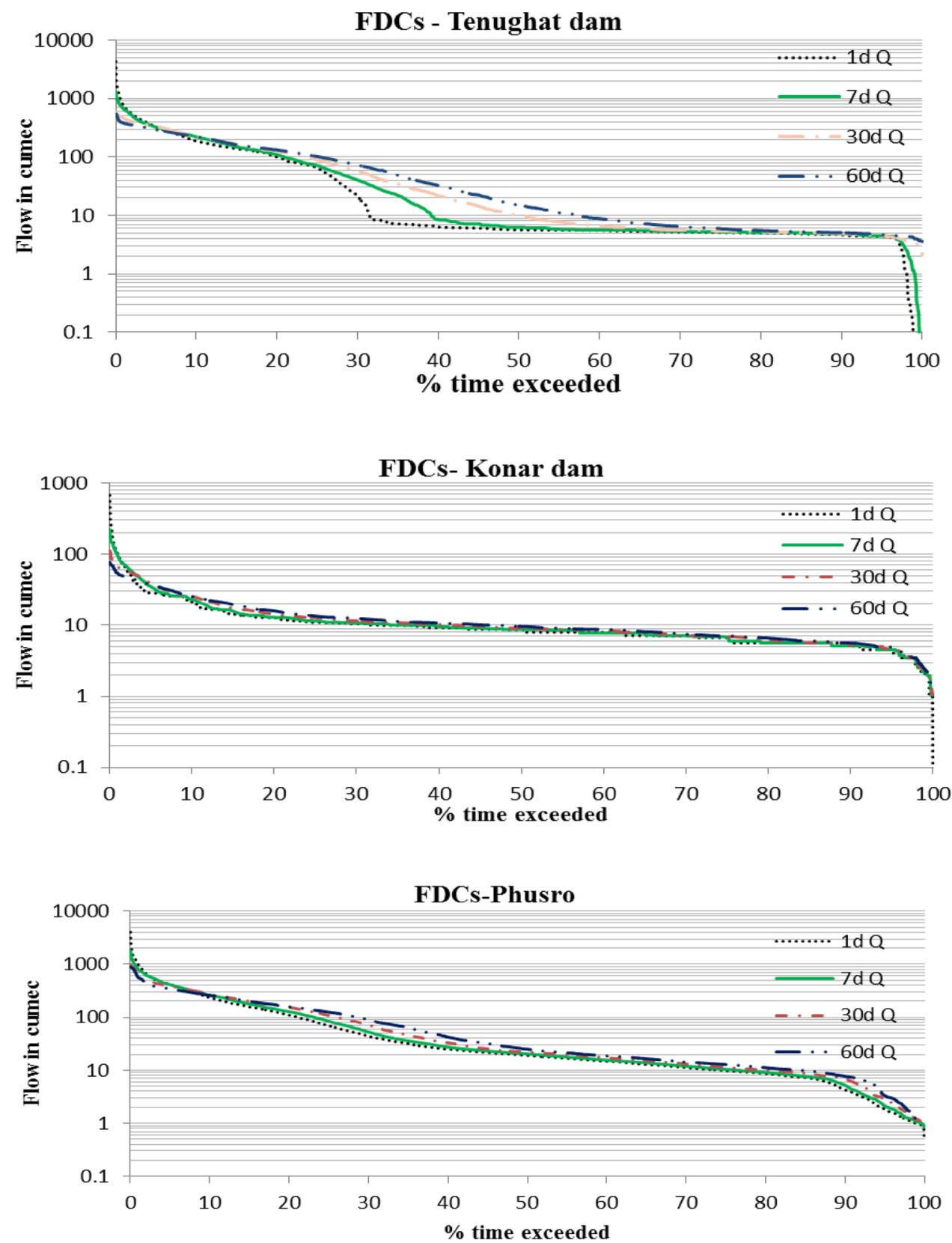

FDCs-Maithon dam

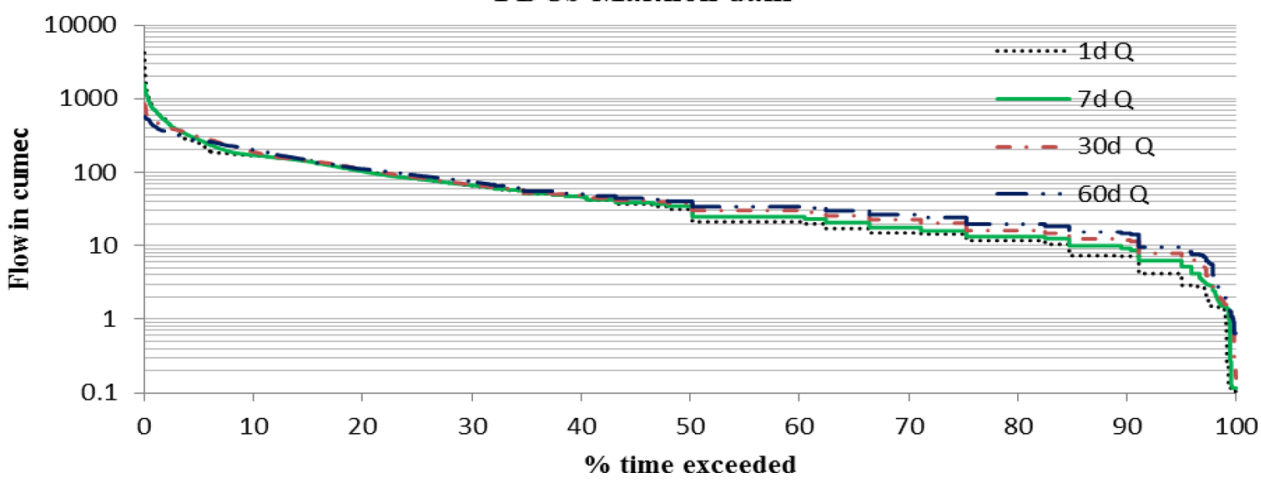




\section{FDCs-Panchet dam}

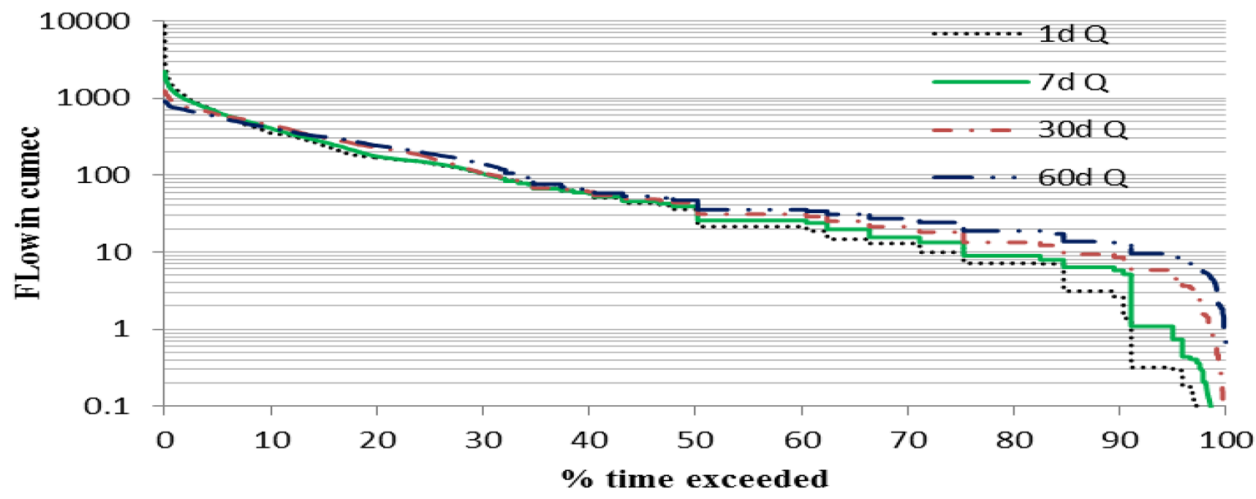

FDCs-Damodar bridge, Burnpur

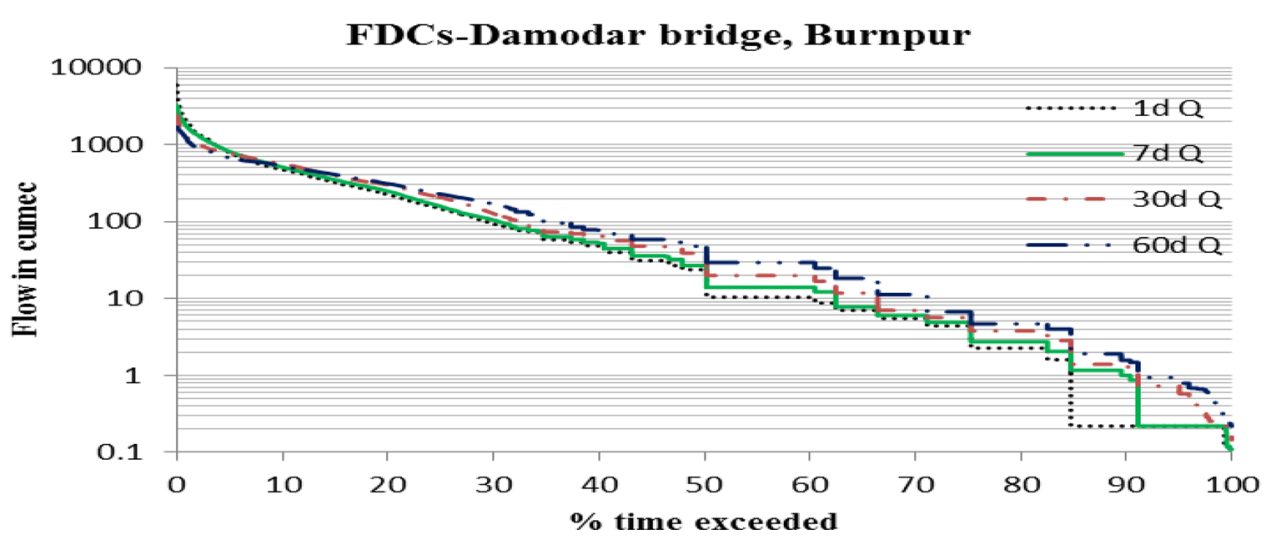

Fig. 3 continued

\section{Results and discussion}

\section{Approach 1}

Figure 3 shows envelops of constructed FDCs using 1-, 7-, 30-, 60-day moving average based on daily discharge data collected from each respective site. The curves show that daily, 7-day mean and 30-day mean FDC plots do not indicate any significant variations. Further, it has been also noted that for a high probability of exceedance, $(5-75 \%)$ of 60 -day mean discharge values are higher than daily, 7-, 30-day values. Considering all the aspects, 7 -day FDC is found to be most suitable, if approach 1 is considered.

Figure 3 also illustrates that the shape of the constructed FDCs at each site differs, which may be due to the difference in precipitation, watershed conditions and other meteorological factors. The upper Damodar watershed is highly urbanized leading to increase in impervious surface, which causes increase in storm water runoff and decrease in infiltration and ground water recharge.

The computed Q95 values corresponding to the probability of exceedance of $95 \%$ from daily, 7- and 30-day mean FDCs at different site are given in Table 2.

\section{Approach 2}

As above, 7-day mean FDC of each year was constructed by plotting and arranging the daily discharge values in descending order. Figure 4 illustrates the plots for the probability of exceedance equal to Q95 at each selected site, which approximately represented by a straight line fit.

Using straight line equations for each percentage exceedance, the discharge values for various return periods of 1-, 5-, 10-, 20-, 50-, and 100-year were developed. The plot of 10-, 20-, 50-, and 100-year return periods at each selected site is shown in Fig. 5. However, low flow values obtained using a return period with 10 years show better agreement with observed values as compared with other FDCs. Furthermore, it has been observed that FDC developed with a return period of 10-year predicts extremely low flow values occurring during drought years and provides realistic results of low flows, which is considered as an environmental design flow (Fig. 6). However, FDC developed with a return period of 100-year predicts higher environmental design flow values, which is necessary to be considered at the planning stage of water resource projects. 
Table 2 Q95 values (cumec) at different site in DRB

\begin{tabular}{lllllll}
\hline Time/sampling site & Tenughat dam & Konar dam & Phusro & Maithon dam & Panchet dam & Durgapur, bridge, Burnpur \\
\hline Daily & 4.39 & 4.05 & 1.86 & 2.89 & 0.29 & 0.22 \\
7-day mean & 4.51 & 4.52 & 2.14 & 5.18 & 0.74 & 0.23 \\
30-day mean & 4.59 & 4.62 & 2.85 & 7.10 & 4.51 & 0.58 \\
60-day mean & 4.68 & 4.88 & 3.37 & 8.25 & 8.53 & 0.79 \\
\hline
\end{tabular}
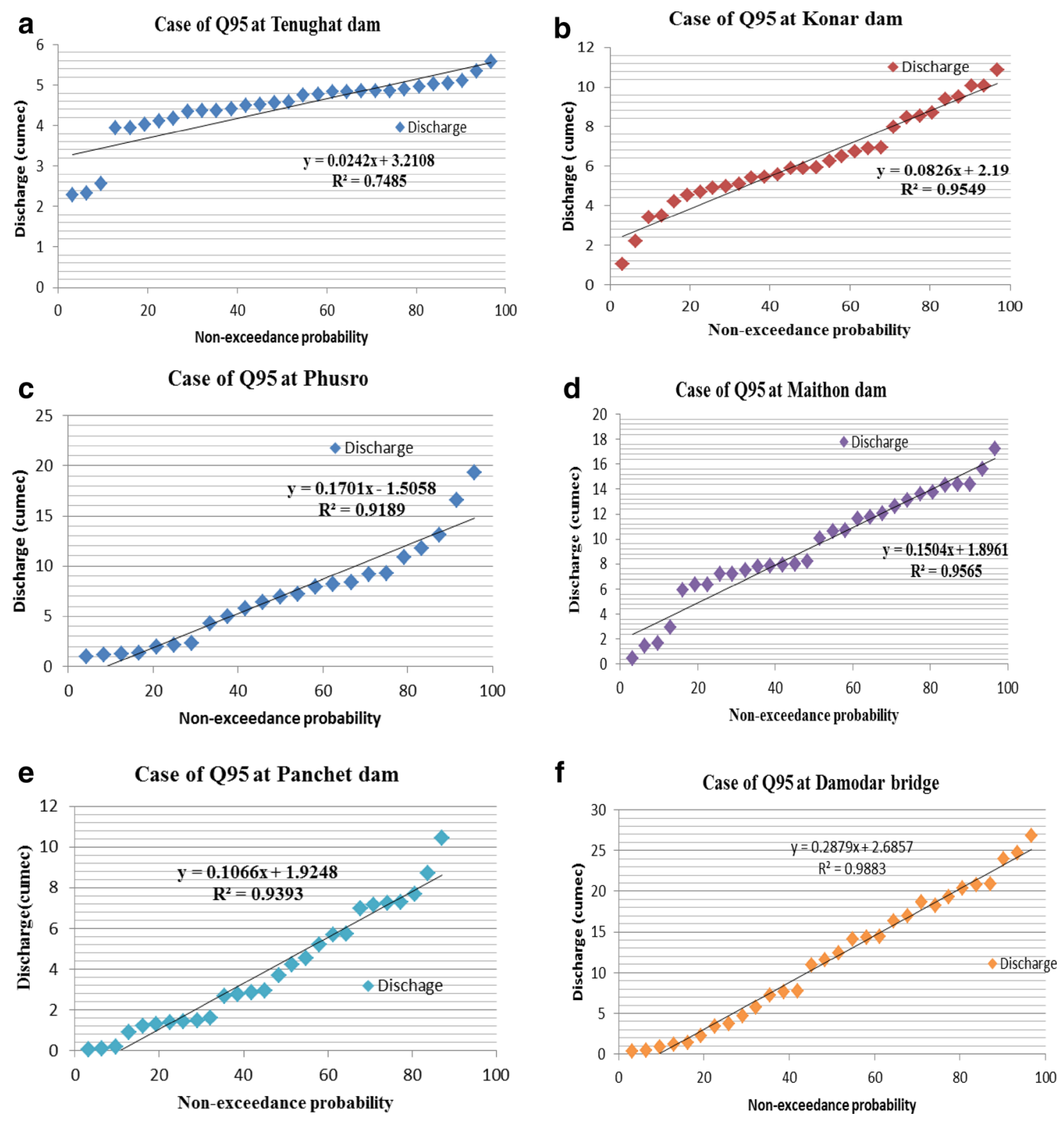

Fig. 4 Best-fit line to obtain discharge values for Q95 probability

Figure 6 indicates the variation of $\mathrm{Q} 95$ for return period of 1-, 2-, 5-, 10-, 20-, 50-, and 100-year. It has been computed that the required Q95 values vary from 3.23 to 5.63 cumec, 2.27 to 10.45 cumec, 1.9 to 3.4 cumec, and 2.03 to 12.58

cumec in downstream reach of Tenughat dam, Konar dam, Maithon dam, and Panchet dam, respectively, while 1.67 to 18.51 cumec, and 2.97 to 31.48 cumec in downstream reach of Phusro and Damodar bridge, Burnpur.

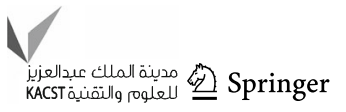



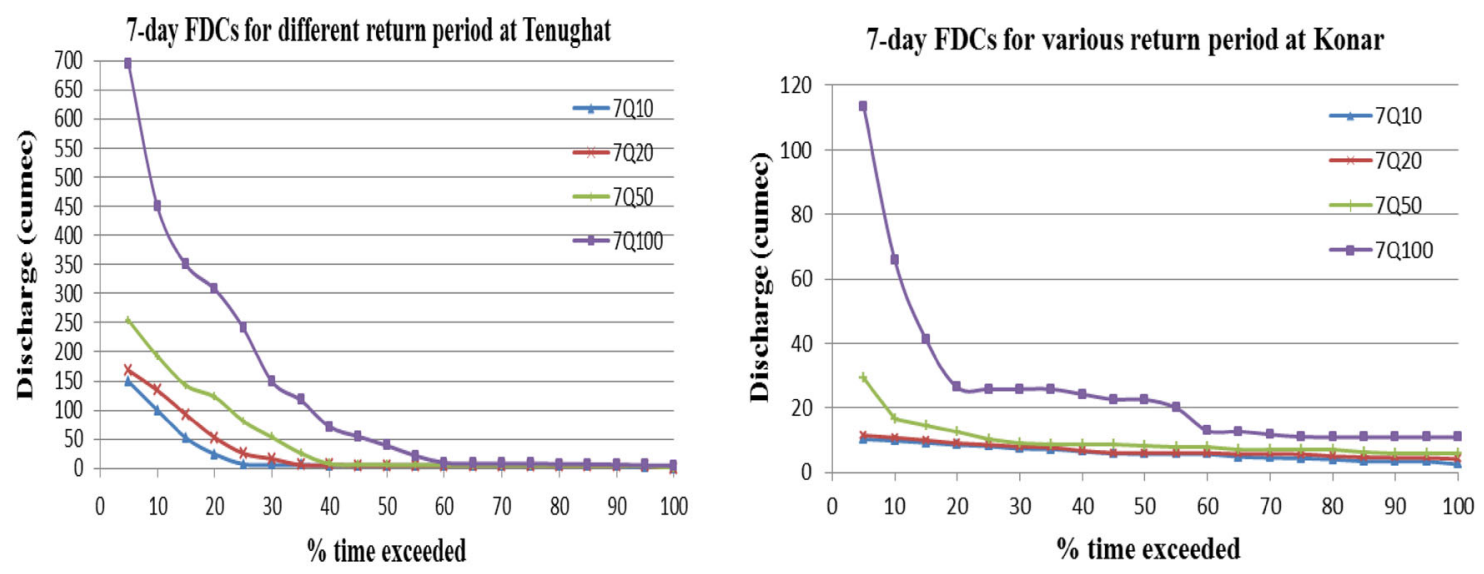

7-day FDCs for different return period at Phusro
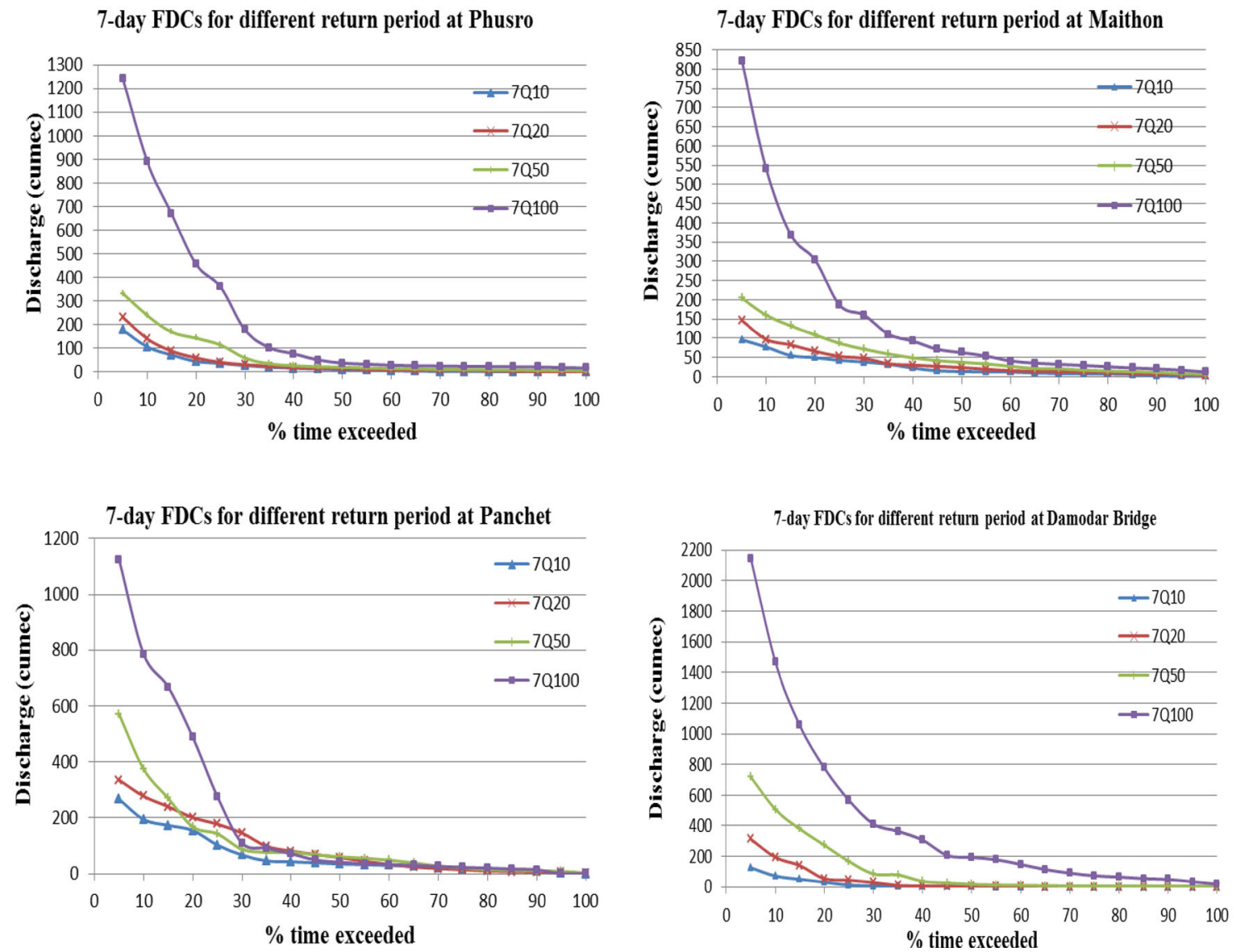

Fig. 5 7-day mean FDCs for 10-, 20-, 50- and 100-year return period at selected sites

\section{Conclusions}

In this study, POR and stochastic FDC approaches were used to assess EFs in six watersheds of DRB. Stochastic approach was used to generate independent extreme low database from historic periods of recorded hydrologic data. The identification of periods of low flows are integral parts of the health of a river ecosystem, which gives confidence in their use.
The value of probability of exceedance equal to $95 \%$ (Q95) of 7Q10 and 7Q100 FDC using the second approach is found appropriate as designed EFs during drought/low flow and normal precipitation years, respectively. The design EFs values for 7Q10 range from 2.04 to 5.56 cumec, whereas for 7Q100 range from 3.4 to 31.48 cumec in DRB.

The 7Q10 flow can be applied for water resource problem like water quality standard maintenance, waste load allocation, and chronic criteria for aquatic life as a part 


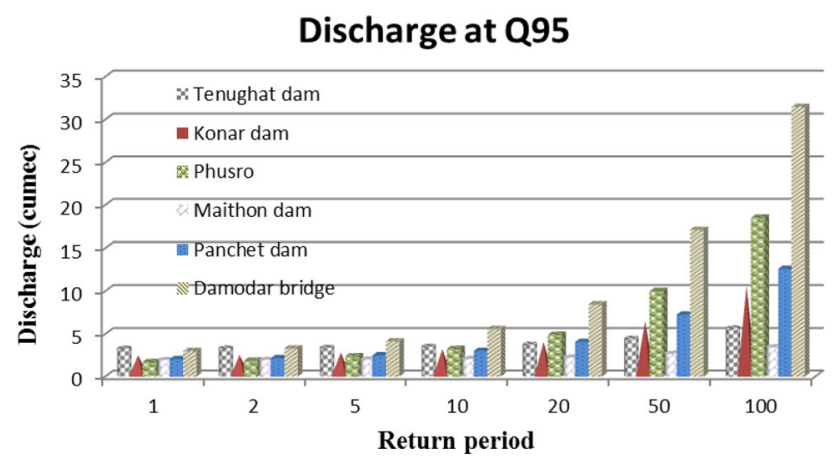

Fig. 6 Design flow discharge for 95\% probability of exceedance

of river basin management. Whereas, 7Q100 values can be also used for long-term planning, development and management of water resources and/or water uses. Finally, it can be concluded that the present methodology would provide insight for river managers and water professionals, where tradeoff is required between water demand for human uses and riverian functions. It could be part of optimized management system that maximizes available water, while sustaining ecosystem.

Acknowledgements The authors are thankful to the DVC, Maithon and the Central Water Commission (CWC), Asansol and Patna division for rendering help in providing data. The first author also thanks the significant help of Dr. Ramakar Jha, Professor, NIT-Patna, India.

Open Access This article is distributed under the terms of the Creative Commons Attribution 4.0 International License (http:// creativecommons.org/licenses/by/4.0/), which permits unrestricted use, distribution, and reproduction in any medium, provided you give appropriate credit to the original author(s) and the source, provide a link to the Creative Commons license, and indicate if changes were made.

\section{References}

Alaouze CM (1989) Reservoir releases to uses with different reliability requirements. Water Resour Bull 25(6):1163-1168

Alaouze CM (1991) Transferable water entitlements which satisfy heterogeneous risk preferences. Aus J Agric Econ 35(2):197-208

Brown LR, Ford T (2002) Effects of flow on the fish communities of a regulated California River: Implications for managing native fishes. River Res Appl 18:331-342

Castellarin A, Vogel RM, Brath A (2004) A stochastic index flow model of flow duration curves. Water Resour Res 40(3):1-10

Chen C, Ma H (2008) The uncertainty effects of design flow on water quality management. Environ Monit Assess 144(1):81-91

Fennessey NM, Vogel RM (1990) Regional flow duration curves for ungaged sites in Massachusetts. I J Water Resour Plan Manag ASCE 116(4):530-549

Foster HA (1934) Duration curves. Trans (ASCE) 99:1213-1267

Gustard A, Wesselink A (1993) Impact of land use change on water resources: Balquidder catchments. J Hydrol 145:389-401

Hughes DA, Hannart P (2003) A Desktop model used to provide an initial estimate of the ecological instream flow requirement of rivers in South Africa. J Hydrol 270(3-4):167-181
Hughes DA, Smakhtin VY (1996a) Daily flow time series patching or extension: a spatial interpolation approach based on flow duration curves. Hydrolog Sci J 41(6):851-871

Hughes DA, Smakhtin VY (1996b) Daily flow time series patching or extension: a spatial interpolation approach based on flow duration curves. J Hydrol Sci 41(6):851-871

Hughes DA, O'Keeffe JH, Smakhtin VY, King J (1997) Development of an operating rule model to simulate time series of reservoir releases for instream flow requirements. Water SA 23(1):21-30

Jha R, Sharma KD, Singh VP (2008) Critical appraisal of methods for the assessment of environmental flows and their application in two river systems of India. KSCE J Civil Eng 12(3):213-219

Lanen HAJ, van Tallaksen LM, Kasparek L, Querner EP (1997) Hydrological drought analysis in Hupsel basin using different physically based models. In: FRIEND'97-regional hydrology: concepts and models for sustainable water resources management. IAHS Publication No., vol 246, pp 189-196

LeBoutillier DW, Waylen PR (1993) Stochastic model of flow duration curves. Water Resour Res 29(10):3535-3541

Male JW, Ogawa H (1982) Low flows of Massachusetts streams. Water Resources Research Centre. Amherst Publication, vol 125 , pp 160

Male JW, Ogawa H (1984) Tradeoffs in Water Quality Management. J Water Resour Plan Manag (ASCE ) 110(4):434-444

Mallory SJL, McKenzie RS (1993) Water resources modeling of flow diversions. In: Proceedings of the Sixth South African Hydrology Symposium. Pietermarietzburg, vol 1, pp 429-436

Mimikou M, Kaemaki S (1985) Regionalization of flow duration characteristics. J Hydrol 82:77-91

Pitman WV (1993) Simulation of run-of-river schemes using monthly data. In: Proceedings of the Sixth South African Hydrology Symposium. Pietermarietzburg, vol 1, pp 445-452

Poff NL, Allan JD, Bain MB, Karr JR, Preste-gaard KL, Richter BD, Sparks RE, Stromberg JC (1997) The natural flow regime. A paradigm for river conservation and restoration. Bio Sci 47(11):769-784

Quimpo RG, Alejandrino AA, McNally TA (1983) Regionalised flow duration curves for Philippines. J Water Resour Plan Manag 109(4):320-330

Reiser DW, Wesche TA, Estes C (1989) Status of instream flow legislation and practices in North America. Fisheries 14:22-28

Searcy JK (1959) Flow-duration curves Paper 1542-A. U.S. Geological Survey Water-Supply. U.S. Government Printing Office, Washington, D.C

Smakhtin VU (2001) Low flow hydrology: a review. J Hydrol 240:147-186

Smakhtin VY, Hughes DA, Creuse-Naudin E (1997) Regionalization of daily flow characteristics in part of the Eastern Cape, South Africa Hydrol. Sci J 42:919-936

Smakhtin VY, Watkins DA, Huges DA, Sami K, Smakhtina OY (1998) Methods of catchment-wide assessment of daily low flow regimes in South Africa. Water SA 24(93):173-185

Sugiyama HV, Vudhivanich AC, Lorsirirat WK (2003) Stochastic flow duration curves for evaluation of flow regimes of rivers. J Amer Water Resour Assoc 39(1):47-58

Tharme RE (2003) A global perspective on environmental flow assessment: emerging trends in the development and application of environmental flow methodologies for rivers. River Res Appl 19:397-441

Vogal RM, Fennessey NM (1994) Flow duration curves. I. A new interpretation and confidence intervals. J Water Resour Plan Manag 120(4):485-504

Wilby R, Greenfield B, Glenny C (1994) A coupled synoptic hydrological model for climate change impact assessment. J Hydrol 153:265-290 